The Sri Lanka Journal of the Humanities (2018) 42: 1-2, 86-104

DOI: http://doi.org/10.4038/sljh.v42i1-2.7256

Published online: 28 November 2019

(c) (i) University of Peradeniya

REVIEW ARTICLE

\title{
Does Authenticity Have a Gender? \\ A Review of Harshana Rambukwella's Book \\ The Politics and Poetics of Authenticity \\ (London: UCL Press, 2018). xi, 164 p.
}

\author{
CARMEN S. WICKRAMAGAMAGE ${ }^{1}$ \\ ${ }^{1}$ University of Peradeniya \\ ${ }^{1}$ carmenwickramagamage@gmail.com \\ 1 (iD) https://orcid.org/0000-0002-9000-1271
}

In Harshana Rambukwella's book, The Politics and Poetics of Authenticity, the attention of the reader is firmly drawn to an aspect of the discourse on (cultural) nationalism in Sri Lanka that has received little critical attention: the quest for authenticity. Quoting the Oxford Dictionary, Rambukwella defines "authenticity" as "veracity, correctness, verisimilitude and the quality of being authoritative and real" (p. 5). In the book, "authenticity" is the term that the author uses to translate into English the high-frequency Sinhala term that figures prominently in Sinhala nationalist discourse: 'ape-kama', a literal translation of which into English, as Rambukwella himself points out, is 'our-ness'. However, contrary to the predilection to conceive or see 
authenticity as what is self-evident or always already there, Rambukwella sees both the interest in authenticity as well as what is seen as authentic as constructed, contextual, and contingent. He also does not see the quest for authenticity as innocent; it is part of an ongoing political and cultural project to consolidate claims to legitimacy. Rambukwella thus offer a nuanced reading of the operation of 'authenticity' as a political and cultural category that functions as a boundary-marker to distinguish, hence separate, an in-group from an outer group, which contributes to the legitimation and authentication of a distinct Sinhala Buddhist identity.

Rambukwella's key question, "how and why of authenticity" (p. 20 ), shows that his approach to the subject is counter-intuitive for one would think that it is in the nature of authenticity to make such interrogation futile. But Rambukwella argues otherwise. For him, the origin, trajectory and purveyance of authenticity are important not simply for a better understanding of our political past and present but also for the sake of our political future given the way the imprimatur of the authentic operates to enfranchise and legitimate some at the expense of others even today. Methodologically, Rambukwella's exploration of the production and reproduction of authenticity through time is pegged to the work of three, key figures whom the author calls "the father figures of Sinhala nationalism": Anagarika Dharmapala, S.W.R.D. Bandaranaike and Gunadasa Amarasekera, ideologue, politician and writer, respectively. All three of them men, what is common in their otherwise diverse personalities, thinking and impacts on (Sinhala Buddhist) national culture is their enduring concern with (cultural) authenticity or 'ape-kama'. It is through their attempts to discover/recover authenticity, attempts that were as much personal as political, that Rambukwella shows the quest for authenticity as a peculiarly Sinhala Buddhist variant of "our" (postcolonial) modernity. ${ }^{1}$

Yet, in this fascinating dissection and disquisition on the thinking of the three figures by a literary and cultural critic, what is missing is the most important, even obvious, signifier of authenticity in

\footnotetext{
1 "Our Modernity" is the term used by well-known postcolonial theorist Partha Chatterjee (1997).
} 
the Lankan context: Woman. For, no group has been called upon, if not pressurized, more to 'embody' and 'preserve' authenticity in their own persons than (Lankan) women. Moreover, though Rambukwella's focus is on the preoccupation with authenticity in Sinhala Buddhist nationalist thinking as represented by 3 of its key ideologues, I would argue that 'woman' as a signifier of 'our' culture, is not absent from the articulations of identity and belonging of the other two major ethnoreligious groupings in Sri Lanka, Tamil and Muslim, which one could argue is perhaps partly the inevitable fallout of its pursuit in the majority Sinhala Buddhist community. ${ }^{2}$ Here I will confine myself by and large to the place of Sinhala (Buddhist) women in this endeavor.

It is surprising why Rambukwella pays little heed to the allimportant place of women in any discussion of 'authenticity' among Sinhala Buddhist nationalist thinkers. In the book, he shows he is not unaware of this role assigned to women when he asserts in page 2 of the Introduction that “[r]egulating women's bodies, attire and behavior was another important manifestation of authenticity in twentieth-century Sinhala cultural nationalism" (p. 2). I would add "twenty-first century," for this attempt at regulating women in the interest of "our culture" remains as current today as it was then. He mentions John de Silva's plays as a significant site of such articulation and through which certain ideas about women attained what Rambukwella calls "visibility and popular circulation" (p. 2), an argument that is also made by Neloufer de Mel in Women and the Nation's Narrative (2003). In fact, the Introduction opens with a reference to a controversy that underscores how very current the concern with "authenticity" or ape-kama is: Kishani Jayasinghe's operatic rendering on Independence Day 2016 of a beloved Sinhala song, Dannō Budungēe, by John de Silva. The controversy reaches a fever pitch when the TV Derana newscaster Sanka Amarajith dismissively characterizes the rendering as akin to a '[female] cat's yowling at night' (the obligatory grammatical gender of the Sinhala language requiring the inflection of animate nouns for gender), which he claimed, in 'our villages', would have been greeted with half a brick

\footnotetext{
${ }^{2}$ See the work of Sittaralega Maunaguru, Sumathy Sivamohan and Farzana Haniffa among others for more.
} 
thrown at the source. ${ }^{3}$ By suggesting that her rendering resembles a female cat's yowling at night, Amarajith introduces a salacious element to Jayasinghe's supposed "desecration" of the venerated song. Thus, the "distortion" by a singer trained in the (western) operatic tradition becomes yet another manifestation of the way inauthentic women compromise pristine and authentic national (Sinhala Buddhist) culture with their enthusiastic embracing of western ways, including (western) sexual mores.

Let me therefore narrate another episode which garnered the same attention around the same time, where too a woman played the lead role and where too there was intense display of anxiety on the part of the men, this time, no less than the President of Sri Lanka. The event I refer to is the "Love \& Sex Concert" by Enrique Iglesias held in December 2015. The day after the Concert, a story began to circulate on social media that a young woman at the concert had removed her bra and thrown it at the singer while another woman (perhaps it was the same young woman?) had run up on stage to embrace the singer. This time it was the President himself who took up cudgels on behalf of "our" culture. At a public event in Ampara where he was addressing an audience on the topic of Buddhist rejuvenation, he asserted that "as a Sinhala Buddhist" he could not condone such conduct and that he considered it his duty to protect "our culture" and to condemn "asamvara $d \vec{e}$ (uncivilized things). ${ }^{4}$ Not stopping at that, he stated that the organizers of such concerts should be whipped with a madu valige (the tail of a sting-ray, a form of punishment that had been used during the reigns of Lankan kings of yore) for making such conduct possible. Of course, he took pains to emphasize that he did not blame the young woman but the organizers of the concert (who happened to be internationally renowned former cricketers)! ${ }^{5}$ Of course, the President's outburst did not go unremarked on social media where it received mainly negative reactions given the age and social class of the users. In

\footnotetext{
${ }^{3} \mathrm{https}: / /$ www.youtube.com/watch?v=TBwIgZZulHI

${ }^{4} \mathrm{https}: / /$ www.youtube.com/watch?v=0V12n9B_7V8

${ }^{4}$ https://www.telegraph.co.uk/news/worldnews/asia/srilanka/12070897/Sri-Lankanpresident-Organisers-of-Enrique-Iglesias-should-be-whipped-as-punishment.html ${ }^{5}$ Daily Lankadeepa, Friday, January 01, 2016, p. 5.
} 
a subsequent speech, a clearly rattled President responded by saying that his political opponents and others were "trying to destroy [him] over this [but that he] won't be the one destroyed, it will be 'our culture'." He again emphasized the importance of 'our-ness', our values and value

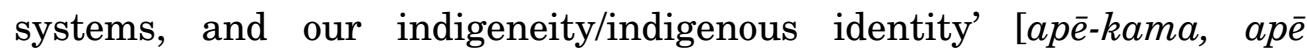
vaținākam, apē hara paddhatīn, désíyatvaya]. Aware perhaps that the sting-ray tail as form of punishment is not in conformity with the current Penal Code, he went on to say that "culture is above the law". ${ }^{6}$

Nothing however underscores the centrality of "women" in locating "our-ness", a pure cultural essence the singularity of which rests in its difference from the "west," as the furor caused this year (2018) over a short-lived proposal by the Finance Ministry to lift the longstanding ban on the sale and purchase of alcohol by women as per Excise Notification 417 of the Ceylon Government Gazette No 100266 of 5.7.1951 (b) and Excise Notification 447 of 29.4.1955, Section 12 (c). ${ }^{7}$ The Ministry's decision to lift the ban, it was said, emanated from purely utilitarian motives: to aid in the promotion of Sri Lanka as a tourist destination, which required that opening hours of bars and restaurants selling alcohol be extended and that the law be revised to make it legal for women to serve in such restaurants. In other words, the deproscription was in no way shaped by a rights perspective, i.e., a desire to implement the equality provision of the 1978 Constitution. The decriminalization however did not last long. Under attack from conservative factions-religious and lay-who claimed that it showed the hypocrisy of the President, Maithhripala Sirisena, who is publicly committed to the eradication of alcohol, tobacco and banned substance use in the country, the President quickly backtracked and re-imposed the ban using his executive powers. He gave no reason for doing so although some political parties of the Opposition and conservative groups had accused him of undermining the nation's Buddhist values, a criticism that would hit home considering that extremist Sinhala Buddhist nationalist factions consistently project the present coalition government headed by Sirisena as being only too ready to accede to directives from the "West", be it on Women's Rights, Human Rights or

\footnotetext{
${ }^{7}$ Sonali Siriwardena, "Old law bars liquor sales to women: Even wine cannot be sold to females!” www.sundaytimes.lk/020421/bus.html
} 
LGBTIQ rights, that would undermine "our" culture. The choice epithet that was once used by the Opposition to characterize this tendency being napumsaka" or eunuch, which underscores the ingrained gender dimensions to post-colonial nation-state making in Sri Lanka. ${ }^{8}$

The criticism however was not confined to the conservative Sinhala Buddhist factions. Samanmali Gunasinghe, the solitary female member in the Politburo of the Marxist-Leninist party, the JVP [Janatā Vimukti Peramuna], was equally critical. She accused the government of a form of "west-mania" and accused it of wanting to create a country of female torpors ( $b \bar{e} b a d d i y \bar{o})$, a phenomenon that would accelerate the destruction of family that has already commenced with the migration of women for work to middle-eastern countries. "If women got drunk, who would wake up early in the morning to prepare meals for the family and be around to assist the kids with their homework?" she asked rhetorically in a newspaper interview. ${ }^{9}$ However, the origins of the ban on alcohol sales to, purchase of, and consumption by women highlight authenticity's recent and impure make-up as the ban has its origins in British colonial era laws. ${ }^{10}$ If that is so, "our-ness", variously paraphrased as "samvvarakama" [discipline], "hædiyāva" [upbringing] and "vaținākam" [values], always expressly located in the local woman, is not as purely local in origin and ancient as it is cracked up to be. However, as also pointed out by newspaper columnist Lucien Rajakarunanayke, the controversy serves to highlight the contradictions

\footnotetext{
${ }^{8}$ The latest such public controversy over 'our culture' or 'ape-kama' unfolded over a series of short radio plays that had been aired or were to be aired soon, some of which adopted and adapted popular Sinhala Buddhist salutations or phrases from Pali stanzas as their titles for satiric purposes. In the ensuing controversy, again the President weighed in to censor the radio broadcasts though they were aired on a state broadcasting channel, ITN FM, and some of them had been sponsored by the Office of National Unity and Reconciliation headed by a former President of Sri Lanka, Ms. Chandrika Kumaratunga (http://www.sundaytimes.lk/180826/news/onur-sponsored-radio-plays-receive-badreception-308172.html). The Minister of Higher Education, weighing in, declared that they were not compatible with 'our culture.'

${ }^{9}$ Ravaya Newspaper, January 21, 2018, p. 5. Translated by the author into English.

${ }^{10}$ For more on the controversy, see https://www.dw.com/en/sri-lanka-lifts-alcoholban-for-women-and-then-quickly-restores-it/a-42154894
} 
that mark the status of women in ("our") culture: in the same year that the Sri Lankan government decided that women could not be trusted to make decisions relating to their personal lives such as imbibing alcohol, that same government also pushed through a $25 \%$ quota for women in Local Government Authorities [LGAs] for the express purpose of increasing the number of women in decision-making positions in governance. ${ }^{11}$ It is this tendency that Radhika Coomaraswamy once characterized as the "Janus-faced" (56) nature of the Lankan state with regard to women. Indian feminist Rajeswari Sunder Rajan saw this tendency in the case of the Indian state as turning (Indian) women into "wards of the state" (47), never full citizens, which she sees as the enduring legacy of the status accorded women in the negotiations for Swaraj or Self-Rule between anti-colonial (elite male) nationalists and British colonialists.

In the case of Sri Lanka, there is a rich scholarship, from widely varying angles, into the ways and means by which authenticity or ape kama has come to be feminized by several Lankan women scholars, among them, Kumari Jayawardena, Malathi de Alwis, Neloufer de Mel, Janaki Jayawardena, Eshani Ruwanpura, Michele Gamburd, Caitryn Lynch, and Sandya Hewamanne, all of whom have looked at how closely women have been associated with the production and reproduction of authenticity from colonial times. As these scholars have shown, women come to be especially hailed by the call to embody authenticity because the claim for separate nationhood is based on the nation's singularity, a singularity determined in terms of its "distance" or "difference" from the "west," a difference that comes to be located in the native women. It is for this reason, as Kumari Jaywardena has argued in her path-breaking classic Feminism and Nationalism in the Third World (1986), that feminists and women's activists find it very hard to chart an autonomous path for women that diverged from that of the "nation." For the same reason, despite the near-simultaneous emergence of Feminism and Nationalism in the Third World, the relationship between feminism and nationalism remains fraught for feminism's projection of women as rights-bearing subjects on par with their male counterparts may not

\footnotetext{
${ }^{11}$ Lucien Rajakarunanayke, "Light Refractions," 'Say 'Cheers' to women who raise their glasses', The Sunday Island, January 20, 2018, p. 10.
} 
cohere with nationalism's projection of women's difference from men. In India, Partha Chatterjee, Lata Mani, Rajeswari Sunder Rajan and Gayatri Spivak have shown how and why the fates of women and nation came to be so integrally linked in the colonial era where the debased status of "native" women had been used to justify the colonial mission as one of rescue or salvation. While there was not the same intense focus on the "degraded" status of women in colonial Ceylon, colonial investment in schools for girls, particularly those begun by Christian missionaries, was not devoid of the rhetoric of civilizing. For the same reason, as Kumari Jayawardena and Malathi de Alwis have written, there was especial concern about women's education among the early nationalist reformers, who expressed anxiety regarding the possible corruption and contamination via "western" education of local women given the desire to locate native "difference" or "indigeneity" in them. What the dispute over women's education or the content of the curriculum for women reveals is the following: that the "authentic" or "ap $\vec{e}$ " local woman did not always already exist fully incarnate in her "pure" difference to be set off against the "western" or "westernized" woman (among local women, the Burgher women and Sinhalese Christian women qualifying for the latter category). She had to be invented.

In her ground-breaking piece, "The Production and Embodiment of Respectability: Gendered Demeanors in Colonial Ceylon", Malathi de Alwis has shown, through careful study of the curriculum for girls of the first (Christian) missionary schools, how a particular type of Respectable Woman or a woman with lajjā-baya [=shame-fear] came to be produced through the imparting of the values of discipline, industry and modesty via a particular type of educational regimen, noteworthy in which was the school bell, time-table, and a curriculum that included Sewing and Embroidery. In a later piece, "Domesticity and its Discontents," she shows how the introduction of "Home Science" (later re-christened as Home Economics") as a subject in the curriculum for girls aided in the same production. Though "respectability" is the English equivalent that de Alwis uses to gloss the local concept of lajjā-baya [a term with historically unspecifiable origins], she argues that the "respectable lady" [or the lady with lajjā-baya] thus produced took on hues and depended on practices that made her more akin to the Victorian/American 
middleclass Christian woman than her unschooled native counterpart. Although pioneers of the Sinhala and Buddhist revival including Anagarika Dharmapala saw the danger of such an education for local women, the more indigenized curriculum of schools that this tussle produced (Buddhist, Hindu and Muslim) did not deviate radically from the curriculum of the Christian missionary schools as the native bourgeoisie saw the value of a formal English medium education for their daughters to make them eligible as marriage partners for men educated under a similar regime among whom there was a demand for such accomplished partners who would be both social assets as well as "enlightened" mothers for their (future) offspring. In her piece, "Domesticity and its Discontents," de Alwis therefore mentions that while Ballroom Dancing came to be removed from the curriculum of such schools due to the objections of nationalist ideologues, piano playing and tennis continued to be offered while Anagarika Dharmapala's suggestions of "a more 'traditional' curriculum which included weaving and meditation" received short shrift (204). One does not have to speculate too much as to where ideas about weaving and meditation came from considering Dharmapala's long-term residence in colonial India.

If Anagarika Dharmapala expressed anxiety about the "hidden curriculum" of colonial missionary schools, particularly their proselytizing tendencies, and seemed keen on an "indigenous" curriculum that would ensure native "difference", as Rambukwella shows, he had little patience or respect for unadulterated versions of the "authentic," i.e., the actual ordinary people, all around him. His Gihi Vinaya, or the Code of Conduct for the Laity, is a good example. Rambukwella mentions the book. What he does not highlight is the inordinate attention it pays to women's conduct. Of the 200 rules laid down for the laity, 30 specifically address women, among them the following: "Women should protect their chastity by showing frequent concern for their husband's wellbeing and not thinking of other men; Women should wear sari blouses which completely cover her breasts, the midriff and the upper back; Women should not address servants with pejorative pronouns; Women should not comb their hair or check for lice in the presence of men; Women should not air their sleeping mats, 
pillows, covering sheets, etc. in places where men pass by; Women should, when their husbands are at home, enquire into the wellbeing of the husband, provide him with water to wash his face, hands and feet; give a clean towel to wipe the face and then offer him food" (qtd. in Ruwanpura, Sex or Sensibility? p. 46). ${ }^{12}$ These rules that abound in "thou shalt nots" hint at the prevalence of the very same practices among the local populace that were not to Dharmapala's liking. Indeed, as Robert Knox in his An Historical Relation of the Island Ceylon (1681) and William Knighton in Forest Life in Ceylon (1854), had observed, their tones heavily laced with opprobrium, in neither her attire nor in her general demeanor did the local women exactly resemble or measure up to the normative local woman that Anagarika Dharmapala and others envisaged or endorsed as the "Ārya Simhala Kula Kāntāva" or Noble Sinhala Lady (Kumari Jayawardena, "Cultural Identity and Sinhala Buddhist Womanhood", 164-65). This woman was the product of concerted effort, in the production and purveyance of which the novels of Piyadasa Sirisena, the various pamphlets of Dharmapala and other likeminded educationists and ideologues, and the early Sinhala-language newspapers all played a part.

Of especial concern in this production of ape-kama or authenticity via local women was regulation of their attire. Dharmapala in particular was not very impressed with the predilection to "western" forms of clothing among women of the local bourgeoisie. As Kumari Jaywardena in Feminism and Nationalism in the Third World points out, by the second half of the $19^{\text {th }}$ century, Ceylonese women of the "rich merchant and conservative landowning families" had taken to British Victorian fashions (120), among them "long skirts and socks, shoes and hats" (Nira Wickramasinghe, 78). Dharmapala sought to counter this trend. But he did not by any means retrieve or resurrect whatever native forms of attire there had been before the infiltration of European styles of dress. Instead, he promoted the Sari as the most suitable attire for local women

\footnotetext{
${ }^{12}$ Eshani Samantha Ruwanpura, Sex or Sensibility? The making of chaste women and promiscuous men in a Sri Lankan university setting (Unpublished Ph.D. Thesis, University of Edinburgh and Queen Margaret University, 2011). She says that the original title of the pamphlet, commonly referred to by scholars as Gihi Vinaya, is possibly Gihi Dina Caryā.
} 
(Jayawardena, Feminism and Nationalism in the Third World, 126). While it is not clear whether it was the "Indian" Sari or the "Kandyan" Osariya that Dharmapala came to endorse and promote, ${ }^{13}$ it is said that Dharmapala's mother, Mallika Hewavitharana, was the first to wear the Sari, the attire promoted in the early $20^{\text {th }}$ century as the 'authentic' local garment for Sinhala Buddhist women. Dharmapala not only endorsed the sari, he gave precise instructions on exactly how it should be worn: "a proper blouse should cover the breast, stomach and back completely. A cloth ten riyans long should be worn as the osariya or saree" (qtd. in Wickramasinghe, Guruge, 37). Instructions regarding a cover for the upper torso of women is instructive for even where a cloth was draped around the lower half of the body among native women, blouses, petticoats and brassieres would have been later additions. As Knox and Knighton, as well as some Christian missionaries, had all observed, covering the upper half of the body was not as ubiquitous a practice as it is today governed as it was by many other criteria such as caste, class, occasion, region and age. Martin Wicramasinghe's Purāṇa Siṃhala Stringē Añuduma (the Dress of Ancient Sinhalese Women) confirms this point (qtd. In Janaki Jayawardena, 37). Dharmapala also attempted to wean the native males from their predilection for "western" or European forms of clothing, an attempt that did not have as much success (Wickramasinghe, 78).

But the crucial point that I wish to highlight here is the 'invention' of "authenticity" in the quest for authenticity as there was nothing inherently local or indigenous about either the Sāri or Osariya. While the Osariya shows the influence of the Nayakkar dynasty on fashions in the Kandyan provinces, the Sāri ${ }^{14}$ was draping style in India that Dharmapala imported to Ceylon from his long sojourn in India. But

\footnotetext{
${ }^{11}$ While Jaywardena in Feminism and Nationalism calls the draping style the "Indian" Sari (126), Nira Wickramasinghe says it was the "Kandyan" Osariya (78). In her most iconic surviving photo, Dharmapala's mother is seen attired in the Osariya.

${ }^{14}$ It should be mentioned that there are different regional draping styles of the 'Sari' even in India (see Wickramagamage, "Unravelling the Story of the Sari," The Sri Lanka Journal of the Humanities, XXIX \& XXX (1\&2) 2003 \& 2004, pp. 179-193; Mukulika Banerjee and Daniel Miller, The Sari, Oxford, UK: Berg, 2003. 277 pp.
} 
the Sari and Osariya are now shorn of their "hybrid" and foreign origins and promoted as signifiers of "authentic" Lankan womanhood, deviations from which style of attire earns women the dreaded labels of "western" and "modern." Hence, even today, the approved attire for female teachers of state-sector schools is the Sāri/Osariya. What is more, an informal dress code requires female parents/guardians visiting the schools to be similarly attired, a sign of one's respectable femininity. In 2017, deviations from the informal dress code by female parents at a private boys' school led to school authorities putting up a notice outside the main school gate listing what is sanctioned and unsanctioned attire for female parents and guardians at the top of which list was the Sāri/Osariya. The sign of course led to an uproar in English speaking circles but it only goes to show that the desire to vest in women markers of authenticity or ape-kama is as much alive today as it was then. ${ }^{15}$ Indeed, were the monolingual Sinhala and Tamil speaking majority consulted on the imposition of dress codes by schools, it is possible that a majority would have seen nothing wrong in it.

Yet the authentication of the culture and the nation or rather the "culture" of the "nation" was not left for long in the hands or the person of a reformed and refined native bourgeois woman. If Dharmapala had little interest in the village and little patience with the uncouth villager, what Rambukwella calls the gradual "twinning of Sinhala and Buddhist identities" (42) and its location in a paddy-cultivation-based agrarian civilization (88-89) by later nationalists such as S.W.R.D. Bandaranaike and Gunadasa Amarasekera gave pride of place to the village and the rural came to be "invested with a sense of new organic authenticity" (105), something we know now as "væva-dāgæba-yāya" [tr. tank-templepaddy field] or "gama-væva-dāgæba" [tr. village-tank-temple], the triple pillars that hold up and sustain 'rata-dæya-samaya' [tr. country-nationreligion]. Of course, Amarasekera had not always identified the village/rural as the repository of the authentic or pure Sinhala Buddhist values if his early novel Karumakkārayo (1955) is anything to go by.

\footnotetext{
${ }^{15}$ For more on this, see https://www.bbc.co.uk/news/world-asia-37451132 and http://www.dailymirror.lk/116404/Dress-code-for-parents-How-incongruous
} 
The village's claim to the authentic rests in its distance from the city, which in contrast is seen as a portal for alien ideas, influences and practices from the "west" that "contaminate" its resident population. Thus, the village is no longer a site lacking in refinement, the uncouth residents of which are entranced by the sophisticated pleasures of the city. Instead, an uneasy tension has come to haunt the relationship between the village and the city. While the villager may be entranced by the city, the city-dweller looks back to the village with nostalgia as a space that he has had to leave behind but life in which is more simple, organic and innocent. This gives rise to the Sinhala equivalent of the Country and the City that Raymond Williams made famous in his book by that name. However, relocation of authenticity from the urban-based middle class to the village-based peasantry would not have been possible without the reinvention of the village woman as the embodiment of this pure and authentic Sinhala Buddhist womanhood, in whom authenticity and purity come to be inextricably intertwined. Today, sidādiye gēnu [or city women] are juxtaposed with the gæmi lan̆dun [or "village lasses"], where the former is a version of the "honey trap" that the male villager, compelled to migrate to the city in search of better prospects, must avoid by keeping alive his faith alive in the purity and innocence embodied by the 'game kella' [=village girl], ${ }^{16}$ the betrayal of whom is a betrayal also of a whole way of life. In this juxtaposition, the city woman is presented as 'samkara' [westernized] and 'asamvara' [undisciplined], someone who has lost her 'gǣnu gati' [feminine traits] along with her 'ape-kama'. Mainstream Sinhala cultural productions, in the form of songs, films and tele-drama contribute much to keeping alive this distinction between the town and the village where a whole constellation of positive attributes come to be attached to the word 'gama' [village]: gamē suvañda [fragrance of the village]; gamē kǣma [village food]; gæmi samājaya [village community]; avihimsaka gæmiyō [innocent villagers]. The valorization of the village and its woman is particularly alive during Avurudu (Sinhala New Year) celebrations when young women sporting long tresses and wearing the "traditional" cloth and jacket are seen making "traditional" sweetmeats and playing "traditional" games, the

\footnotetext{
${ }^{16}$ Samitha Mudunkotuwa's Sinhala song “Kolompurē Numba Innā Isavvē" elicits this sentiment very well.
} 
mixed origins of these items-attire, food and games-all blissfully forgotten. Ultimately, as the test of authenticity becomes its perceived distance from western influences and sources, authenticatable authenticity recedes into the distance, forever unattainable, while a simulated authenticity depending on the market and circulated by the print and electronic media takes its place.

Yet, this elevation to the status of the "authentic" woman is not without its pitfalls to the village women or 'gæmi lan̆dun' thus elevated whose perceived loss of that "authenticity" in society's eyes could subject them to punitive sanctions. In the work of Caitryn Lynch and Sandya Hewamanne, both of whom write about female apparel manufacturing workers, the claims of "authentic village womanhood" on rural women, who work in garment factories in search of a better life, carry both positive and negative repercussions. In the case of workers in the "200 Garment Factory Programme" [200 GFP] located in rural settings, this requirement leads the women workers to consciously adopt a demeanor that projects them as "Good Girls" despite their insertion into the modern capitalist workforce setting themselves apart from those "Bad Juki Girls" working in factories located in urban-based Free Trade Zones (Caitryn Lynch, 18-22). In the case of workers who have migrated to the urban FTZ factories, as Sandya Hewamanne shows, this perceived "fall" from grace (or rather rurality) of the village women workers exposes them to many different types of harassment and even sexual exploitation and violence (Hewamanne, 2009 \& 2011). Indeed, as Lynch points out, President Premadasa, whose brainchild the 200 Garment Factory Programme was, wanted the factories located in close proximity to villages, in order to allay the anxieties of a mainstream moral and cultural order that saw the "loss" of village womanhood to the allure of "filthy lucre" in cities as the final body blow to ape-kama $\cdot{ }^{17}$ Indeed, the landmark change in trade and economic policies of the country in 1977, also known as the "open economy," which led to the advent of FTZs is today lamented in certain patriotic nationalist circles as the debasement of a feminized nation and culture. Nanda Malini's song "Mægē Nama

\footnotetext{
${ }^{17}$ For more, see Caitryn Lynch. Juki Girls, Good Girls: Gender and Cultural Politics in Sri Lanka's Global Garment Industry. Ithaca, NY: Cornell University Press, 2007.
} 
Lamk $\bar{a}$ " powerfully articulates the twinning of women and nation in expressions of this sentiment:

mægē nama laṃkā

dharmādhikaraṇayaṭa kæñdavīmi svāmīni mǣ...

mægē nama laṃkāya... indiyan sāgarē vasannī...

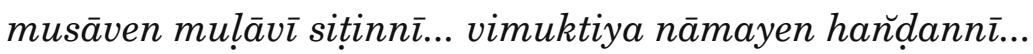

upata læba bohō kal somnasin visuvāya mǣ...

malvarava nāmbarava babalamin sițiyāya mǣ...

sallāla pāśayen bohō vara miduṇāya mǣ...

sita dubala vū dineka viyavulehi væțunāya mǣ...

kumari bambasara pudā neka gæhæța vindāya mǣ...

salelunața rævațemin siya rusiru piduvāya mǣ...

isuru san̆dahā ovun ukasațada tæbuvāya mǣ...

asaraṇava ada mesē mahamagața væțuñāya mǣ...

[Translation of the Song]

This woman has been asked to appear

before the Court of Justice.

Chorus: This woman's name is Lanka

She lives in the Indian Ocean

She is deceived by lies

She is crying out for freedom.

After her birth, for a long time, happily lived she,

As a young woman, after attaining puberty, sparkled she,

From the snare of seducers many times escaped she,

But on a day when weak in mind fell into trouble she.

Sacrificed her virginity and suffered a lot she,

Deceived by scoundrels, her blood sacrificed she,

For wealth, mortgaged herself she

Helpless out on the streets now is she. 
But if the call to consumerism by mercantile capitalism is perceived to exert pressure on local women to depart from the call to "ape-kama" or authenticity, the long-drawn-out Civil War which threatened the lineaments of the nation-state exerted a counter-pressure on women (of all major communities) to embody the putative ethnocultural exclusivity of the "nation" on their own bodies. Of course, men too had a role to play vis-à-vis the feminized nation: its defenders. Identified as they were with the nation, women's role was different. They had to ensure its survival through the literal and figurative reproduction of its future citizens. Much-loved early songs such as C.T. Fernando's "Mā Bāla Kāle" remind us in no uncertain terms where the woman's worth lies: as Mother. Of course, this role as mother elevates women to a high place in nationalist discourse. During the War, this meant bearing and rearing "brave" sons for the nation and willingly sacrificing them in defense of the nation. But it also earns those women who, for whatever reason, fail to strive for this revered goal much opprobrium. Women's worth in other words lies in their procreative capacity within wedded motherhood. During the time of Civil War, the rape of "enemy" women then was not simply manifestations of bestiality on the part of individual soldiers but collective punishment for an "ethnic" enemy understood as male. Sexual penetration of the woman was a symbolic penetration of the nation as many feminist scholars have pointed out. Of course, this is not to deny that the burdens of a long drawn-out war had led to changes in the normative gendered division. Women could not long remain the nation's mothers exclusively. They had to join the military; they became widows and heads of household; they had to migrate to West Asia for work or eke out other forms of income-generating labor to make ends meet, particularly as the state backtracked on welfare provisions burdened as it was with the costs of war. But what Rambukwella calls "authenticity's" protean nature has managed to survive all such challenges. The belief in 'ape- $k a m a$ ' persists. Women remain its primary standard-bearers.

Nevertheless, authenticity's attempts to corral women in its cause has not been without its detractors. If the discourse on authenticity, as Rambukwella points out, could become a punitive discourse for those lacking in authenticity, Lankan women have not 
always meekly accepted their subjection to the discourse without dissent. They have used the discourse for their own ends as with the "good girls" of the 200 Garment Factory programme. And then there are the "Gulf" workers or the "Juki" girls for whom "authenticity" comes with a price tag that they are unable to afford. Also amongst its detractors are the feminist scholars who continue to regard the discourse from a critical eye, highlighting its contingent and constructed nature. These interventions, intentional or otherwise, make 'ape-kama' or authenticity a little less certain; a little more fluid, despite attempts to hold it in place.

\section{Works Cited}

Bannerjee, Mukulika \& Daniel Miller, The Sari, Oxford, UK: Berg, 2003. $277 \mathrm{pp}$.

Chatterjee, Partha. "The Nationalist Resolution of the Women's Question." Recasting Women: Essays in Colonial History. Ed. Kumkum Sangari \& Sudesh Vaid. New Delhi: Kali for Women, 1989. pp. 233-254.

Coomaraswamy, Radhika. "To Bellow like a Cow: Women, Ethnicity, and the Discourse of Rights." Human Rights of Women: National and International Perspectives. Ed. Rebecca Cook. Philadelphia: University of Pennsylvania Press, 2011. Project MUSE, August 2018.

De Alwis, Malathi. "Domesticity and its Discontents." At the Cutting Edge: Essays in Honour of Kumari Jayawardena. Ed. Neloufer de Mel \& Selvy Thiruchandran. New Delhi: Women Unlimited, 2007. pp. 183-219.

---. "The Production and Embodiment of Respectability: Gendered Demeanors in Colonial Ceylon." Sri Lanka: Identities Revisited. Ed. Michael Roberts. Colombo: SSA, 1998.

De Mel, Neloufer. Women \& the Nation's Narrative: Gender and Nationalism in Twentieth-Century Sri Lanka. New Delhi: Kali for Women, 2001.

Haniffa, Farzana. "Piety as Politics Amongst Muslim Women in Contemporary Sri Lanka”. Modern Asian Studies. Vol. 42, No. 2/3. Islam in South Asia (Mar.-May, 2008). pp. 347-375.

---. "Under Cover: Reflections on the Practice of "Hijab" amongst Urban Muslim Women in Sri Lanka." N.D. N.P. 
Hewamanne, Sandya. "Duty Bound? Militarization, Romances, and New Forms of Violence among Sri Lanka's Free Trade Zone Factory Workers." Cultural Dynamics. 21 (2009): 153-184.

---. "Negotiating Sexual Meanings: Global Discourses, Local Practices, and Sri Lanka's Free Trade Zone (FTZ) Factory Workers." Ethnography. 13.3 (2011): 352-374.

Jayawardena, Janaki. Cultural Construction of the 'Sinhala Woman' and Women's Lives in Post-Independence Sri Lanka. Unpublished Ph.D. Thesis. University of York Centre for Women's Studies, October 2002. Jayawardena, Kumari. Feminism and Nationalism in the Third World. London: Verso, 1986.

---. "Some Aspects of Religious and Cultural Identity and the Construction of Sinhala Buddhist Womanhood." Religion and Political Conflict in South Asia: India, Pakistan, and Sri Lanka. Ed. Douglas Allen. Delhi: Oxford University Press, 1993. pp. 160-180.

Knighton, William (1854), Forest Life in Ceylon, Vol. I \& II, New Delhi: Asian Educational Services, Reprint 1998.

Knox, Robert (1681). An Historical Relation of the Island Ceylon, $2^{\text {nd }}$

Edition. Ed. J.H.O. Paulusz. Vol. 1 \& 2. Colombo: Tisara Prakasakayo Ltd., 2009.

Lynch, Caitryn. "Good Girls or Juki Girls? Leaning and Identity in Garment Factories.” Anthropology of Work Review. XIX.3 (1997), 18-22.

Mani, Lata. "Contentious Traditions: The Debate on Sati in Colonial India." Recasting Women: Essays in Colonial History. Ed. Kumkum Sangari \& Sudesh Vaid. New Delhi: Kali for Women, 1989. pp. 233-254.

Maunaguru, Sitralega. "Gendering Tamil Nationalism: The Construction of 'Woman' in Projects of Protest and Control." Unmaking the Nation: The Politics of Identity and History in Modern Sri Lanka. Ed. Pradeep Jeganathan \& Qadri Ismail. Colombo: SSA, 1995.

Ruwanpura, Eshani Samantha. Sex or Sensibility? The Making of Chaste Women and Promiscuous Men in a Sri Lankan University Setting. Unpublished Ph.D. Thesis. University of Edinburgh and Queen Margaret University, 2011.

Sivamohan, Sumathy. "Emdbodied Nation: Martial Feminism and the Cultural Production of Sri Lankan Tamil Women." N.D. N.P. Sunder Rajan, Rajeswari. "The Ameena 'Case': The Female Citizen and Subject." The Scandal of the State: Women, Law and Citizenship in Postcolonial India. Durham: Duke University Press, 2003. pp. 42-72. 
Wickramagamage, Carmen. "Unravelling the Story of the Sari," The Sri Lanka Journal of the Humanities, XXIX \& XXX (1\&2) 2003 \& 2004. pp. 179-193.

Wickramasinghe, Nira. "From Hybridity to Authenticity: the Biography of a few Kandyan Things," The Hybrid Island: Culture Crossings and the Intention of Identity in Sri Lanka. Ed. Neluka Silva. Colombo: SSA, 2002. pp. 71-92.

Zackariya, Faizun \& Zulfika Ismail. "Early Marriage and Perpetuation of the Cycle of Violence in a Displaced Situation: A Question of Culture, Rights or Resistance?" Confronting Complexities: Gender, Perceptions and Values. Colombo: CENWOR, 1998. pp. 25-51. 